\title{
Corporate decision-making in R\&D outsourcing and the impact on internal R\&D employment intensity
}

Peter Teirlinck*,**-Michel Dumont ${ }^{\circ}-$ André Spithoven $^{+}$

* Belgian Science Policy Office, Belgium, peter.teirlinck@belspo.be; Vrije Universiteit Brussel, Belgium. Rue de la Science 8, 1000 Brussels, Belgium, tel: +32(0)2 238.34.59; fax: +322230.59 .12$

- Federal Planning Bureau, Belgium, dm@plan.be; Delft University of Technology, The Netherlands and University of Antwerp, Belgium. Kunstlaan 47-49 - 1000 Brussel, tel: +32 (0)2 507.73.85

${ }^{+}$Belgian Science Policy Office, Belgium, andre.spithoven@belspo.be; Vrije Universiteit Brussel, Belgium. Rue de la Science 8, 1000 Brussels, Belgium, tel: +32 (0)2 230.34.82

** Corresponding author

\section{Abstract}

This paper aims to assess whether firms' strategies of R\&D outsourcing determine changes in their internal R\&D employment intensity. Four strategic decisions are investigated: to start, increase, decrease or stop outsourcing. It is found that internal R\&D employment intensity decreases when firms decide to start or to increase R\&D outsourcing. However, this finding hides important differences according to the type and location of the contractor. Starting to outsource to research centers in the proper region seems to decrease internal R\&D employment intensity, whereas the opposite is true in case of outsourcing to firms and universities outside the proper region.

Key words: $R \& D$ outsourcing, internal $R \& D$ employment, type and location of contractor 


\section{JEL-classification: O32, D21, L24}

\section{Introduction}

Outsourcing activities spur a heated debate among economists and the public at large (Chesbrough, 2003; Howells et al., 2008). Not that buying goods and services from suppliers is something new, but because surging outsourcing (off shoring) is feared to displace domestic employment. Due to the rising educational level of the population in most developed countries, the outsourcing of low-skilled labor did not create alarmist tidings. But with the increasing division of labor at firm level, the availability of specialized knowledge outside the firm boundaries, the need to remain competitive through innovation, and the swift development of emerging economies like India and China, R\&D outsourcing is believed potentially to affect high-skilled employees and to displace R\&D jobs.

This paper focuses on the impact of firm-level decisions to start, increase, decrease or stop R\&D outsourcing, on the R\&D employment intensity. This topic can be related to the important change in strategic $R \& D$ management in the 1990 s towards an increasing intensification of companies' dependence upon external sources of technology, including a trend towards more outsourcing (Coombs et al., 2003; Edler et al., 2002). Quinn and Hilmer (1995) attributed this tendency to the corporate strategies of firms to subcontract non-core or peripheral tasks. The higher reliance on external sources is considered part of a fundamental shift in the way companies generate new ideas and bring them to the market, as emphasized by the concept of 'open innovation' (Chesbrough, 2003).

The empirical literature on R\&D outsourcing showed a high interest in the determinants for R\&D outsourcing (Mol, 2005), in the topic of competition between R\&D outsourcing with the internal $\mathrm{R} \& \mathrm{D}$ activities stressing the question of complementarity versus substitution effects (Veugelers, 1997), and in the search for the 'optimal' level or balance between in-house and outsourced R\&D (Belderbos et al., 2004). These analyses mainly considered budgets for R\&D outsourcing.

To our knowledge, empirical evidence on the effects of the outsourcing of R\&D on the composition of skills in the total labor force of the firm, and more precisely the relative 
importance of $R \& D$ workers (i.e. the internal $R \& D$ employment intensity) remains a blank spot in the literature. Studying this topic is in line with research investigating the impact of technological change on employment in terms of changes in the quality of employment. The literature on open innovation rightfully acknowledges that firms can never have all the expertise intra-muros (Chesbrough, 2003); but also acknowledges that for their core activities the best brains better work for the firm to be able to incorporate the external ideas into profitable innovation (Quinn, 2000; Cohen and Levinthal, 1990). These arguments draw attention to the effects of outsourcing on the labor composition at the firm level.

This paper contributes to the empirical literature on $R \& D$ outsourcing in several ways. First, the topic is approached in a dynamic framework, using a panel of permanent $R \& D$ active firms. In contrast to extant empirical studies, the $R \& D$ budgets involved in outsourcing are complemented with the strategic decision of the firm to start, to increase, to decrease or to stop $R \& D$ outsourcing. Second, the effects of $R \& D$ outsourcing on the dynamics of internal $R \& D$ employment intensity (measured in terms of the evolution in the share of R\&D employment in total employment at the firm level) are the central issue in this study. $R \& D$ employment, more than $R \& D$ budgets, is a vital element of the knowledge base of the firm and as such cannot be made redundant without careful consideration (Quinn, 2000). Third, R\&D outsourcing is refined by taking the type and location of the contractor on board. The type of contractor varies between other (non-affiliated) firms, universities, and public and private research centers (von Hippel, 1988; Tether, 2002). Outsourcing to universities is likely to be more associated with basic research and the resulting path from invention to commercialization might be longer than in the case of applied research by suppliers directed towards troubleshooting. Consequently the choice of partner is not without relevance. Next, the location is taken into account because geographical proximity exerts an impact on the interaction possibilities (Teirlinck and Spithoven, 2008), because of the labor cost argument put forward in the off shoring literature (Sorenson et al., 2006; Cusmano et al., 2008), and because of cultural factors (Hofstede, 1991). A distinction can be made between outsourced R\&D performed within the region, the country, and abroad (OECD, 2002).

The paper is organized as follows. Section 2 pictures the theoretical background on $R \& D$ outsourcing and relates this to the internal $R \& D$ employment intensity. The main 
drivers of R\&D outsourcing are identified as well as the relation between outsourcing and the internal R\&D employment intensity. Next, the importance of the type and the geographical location of contractors are discussed. From this literature review the main research questions are derived. Section 3 describes the nature of the dataset, the sample and the method used. Next, in section 4, the data analysis is carried out and the results are discussed. The concluding section focuses on the main findings, offers some implications for practitioners and policy, and identifies some limitations of the analysis.

\section{Theoretical background}

\subsection{Firm motives for R\&D outsourcing}

From a firm's point of view, the decision whether to perform R\&D activities internally or to outsource them can be approached from a cost perspective (Quinn, 2000) or from an external technology sourcing based view (in line with the ideas of distributed or open innovation, Chesbrough, 2003).

From a cost perspective, firms have to weigh the costs of outsourcing a given activity against the cost of conducting it in-house. Williamson's (1975) ideas on transaction costs include both the direct costs of the transaction and the possible opportunity costs of inferior governance decisions (Holmstrom and Milgrom, 1994). With low uncertainty, reduced asset specificity and low frequency of iteration, firms will prefer a market transaction to internalising the activity (Williamson, 1985). However, as is often the case in R\&D projects, transaction cost economics underline the risks of outsourcing activities based on specific assets or under conditions of uncertainty.

From a technology sourcing based view a distinction can be made according to whether or not the outsourced activities belong to the core activities of the firm. On the one hand, outsourcing non-core activities allows firms to increase managerial attention and resource allocation to those tasks they do best (Gilley and Rasheed, 2000; Narula, 2001). On the other hand, R\&D outsourcing of more core-related activities facilitates the access of fresh knowledge and new technology and helps benefitting from complementary capabilities. However, appropriation of the results of outsourced R\&D is an important 
element in this type of activity (Teece, 1986; Chesbrough, 2003). R\&D aimed at the provision of enhanced information transfer and coordination across activities within the knowledge production system (implying second- and higher-order interactions among a set of value-chain activities) is confronted with more concerns of appropriation than R\&D directly tied to the ability to identify, isolate, or solve a specific set of independent technical problems (Cassiman et al., 2005). The necessity of absorptive capacity suggesting that the impact of internal and external technology on firm performance is not independent supports this argument (Cohen and Levinthal, 1990).

Empirical evidence reveals that $R \& D$ outsourcing is driven by the lack of in-house R\&D and technical expertise, followed by the reduction of development time and time to market (Howells et al., 2004, 2008). Reducing development costs ranked only in third place, followed with some distance by the reduction of risk (see also Mehta and Peters, 2007) and uncertainty by sharing R\&D with another (set of) partner(s). These drivers should be seen in conjunction with a greater codification of R\&D processes (Granstrand et al., 1992; Narula, 2001). A main driver for R\&D outsourcing includes the set-up of strategic research projects where partner firms or institutions possess complementary technological capabilities not available in-house (e.g. Pisano, 1990, Chesbrough, 2003).

These empirical findings are not fully in line with the normative logic that technology outsourcing alliances allow the outsourcing firms to further specialize in their domain of core competence without being distracted by non-core activities (see e.g. Coombs, 1996). However, it does confirm the finding that 'peripheral' knowledge (i.e. specialized knowledge in the domain of outsourced activities) complements control in technology outsourcing alliances (Brusoni et al., 2001, Mehta and Peters, 2007, Tiwana and Keil, 2007).

The potential downside of $R \& D$ outsourcing is that this kind of activities may induce an element of external technology dependence (Swan and Allred, 2003), enhance organizational cost (Jacobides and Billinger, 2006) and weaken the integration between production and R\&D (Teece, 1986). Another concern is the possible deterioration of internal innovation capacity and loss of comparative advantage. Outsourcing R\&D also means that other parties are provided with information about the firm and its products and 
reduces both the exclusivity of the resulting new knowledge and the ability of the firm to appropriate the results of its (outsourced) R\&D (Arrow, 1962).

According to Antras (2005), the transfer of new technology should usually be conducted internally, while that of technology between five and ten years old can be completed through outsourcing. This confirms earlier findings by Mansfield and Romeo (1980). Davidson and McFetridge (1984) find that the probability of outsourcing is lower the more radical the technology and the larger the R\&D department of a firm. Other studies indicate that, in general, outsourcing is more frequent the more codifiable and less complex the technology is - with complexity being measured through the amount of R\&D necessary to produce a good (Wilson, 1977; Kogut and Zander, 1993). Similarly, Trefler (2005) argues that outsourcing is the appropriate way for a sufficiently routine project that can be fully scoped or described, while projects difficult to describe from the outset should be conducted in-house. When the task outsourced is specific there are fewer risks involved, since contract design, enforcement and monitoring are relatively easy.

Finally, it has to be recognized that the use of external sources is also influenced by more generic elements. A first element relates to the technological opportunities in a given industry (Klevorick et al., 1995). The openness of individual firms to external sources of knowledge is subject to a degree of firm-level decision, but many of these decisions are shaped by the search activities of other firms in their industry and by the nature of the environment in which they operate (Cohen and Levinthal, 1990; Nelson and Winter, 1982). Laursen and Salter (2006) found that the higher the technological opportunities offered by the industry in which firms are operating, the higher the degree of openness to external sources of innovation. A second element can be related to firm size. In this respect, and in support of Chesbrough (2003), Laursen and Salter (2006) found larger firms more likely to be open to external knowledge due to the higher availability of resources and innovations which are more complex in nature.

\subsection{The relation between $R \& D$ outsourcing and internal $R \& D$ employment intensity}

It is widely accepted that access to external technology, in combination with the presence of internal R\&D necessary to absorb external knowledge (Cohen and Levinthal, 1990) 
allows firms to improve the performance of internal R\&D efforts (Cassiman and Veugelers, 2006). In addition, internal R\&D enables firms to translate external knowledge into innovation opportunities and outsourced R\&D facilitates spillovers from outside the network to the firm's specific knowledge base (Audretsch et al., 1996).

In line with these arguments, several empirical studies found a positive relationship between the share of external R\&D in total R\&D and productivity (Bönte, 2003; Beneito, 2006; Griffith et al., 2004). Firms with high levels of absorptive capacity were found likely to be more open to external $R \& D$ because retaining skills and expert staff enables them to access wider networks (Rosenberg, 1990). Knowledge intensive small firms were less likely to be involved in this kind of activity because they often rely on the exploitation of new ideas and given the danger they face from leakage of their ideas, they limit the nature and scope of their external interaction (Laursen and Salter, 2006).

Evolutionary economics provides a different perspective on the effects of outsourcing knowledge-intensive or strategic activities, by stressing the impact of changing firm boundaries on the dynamic capabilities of the firm, and hence on its ability to integrate, build and reconfigure internal and external competencies to address changing environments (Teece et al., 1997). In this respect outsourcing is seen as part of a knowledge-searching strategy in which external actors contribute in the division of labour in research tasks and complement in-house R\&D (Arrora and Gambardella, 1990; Chesbrough, 2003).

However, empirical evidence does not always support the idea of complementarity between internal and external R\&D. Based on a cross-section of Dutch manufacturing firms, Audretsch et al. (1996) reported a substition effect of external R\&D activity in low and medium technology industries (the reverse was true in high-tech industries). Cassiman and Veugelers (2006) found that firms combining internal and external R\&D strategies for innovation show superior innovative performance. It also turns out that large, resourceful firms have a higher propensity to combine both strategies (Veugelers and Cassiman, 1999). Piga and Vivarelli (2004) modelled the decision to outsource R\&D jointly with the decision on internal $R \& D$ and found that firms having larger internal $R \& D$ expenditures and pursuing broader objectives related to both process and product innovation have a greater propensity to engage in R\&D outsourcing. 
In contrast with the interest in the topic of complementarity of - or substitution by R\&D outsourcing, to our knowledge, empirical evidence on the effects of the outsourcing of $\mathrm{R} \& \mathrm{D}$ on the composition of skills in the total labour force of the firm, and more precisely the relative importance of $R \& D$ (i.e. the internal $R \& D$ employment intensity) remains a blank spot in the literature. Studying this topic is in line with studies investigating the impact of technological change on employment in terms of changes in the quality of employment. Relying on evidence in this broader context, Segan and Sullivan (1997) and Kahn (2000) reveal that technological standardization - which drives the growth of outsourcing - reduces the importance of firm-specific knowledge, as standardization reduces the specificity of internal skills and induces convergence of firm-specific skills to general skills over time. Pianta (2004) studied - at macro level - the impact of technological innovation on the quality of jobs by looking at the relative importance of skilled and unskilled jobs and found the diffusion of technologies to have a strong skill bias effect in favor of skilled jobs for educated workers. Tarabusi (1997) also found a trend towards skill upgrading, but revealed that the effects on qualifications depend on the importance of the nature of technology and the context in which technological changes are embedded. The latter finding is in line with the management literature (see e.g. Tushman and Anderson, 1997; Piva et al., 2003; Chesbrough, 2003) highlighting the importance of the organizational context for changes in the skill composition of employment.

This argument can be extended to $R \& D$ outsourcing at the firm level by investigating the impact of firms' decisions in terms of technology sourcing (by means of $R \& D$ outsourcing) on the relative importance of $R \& D$ skills in total firm employment. This relates to the question whether, and if so, in which direction, firm level decisions in terms of R\&D outsourcing change the relative importance of $R \& D$ labor in total employment.

\subsection{The importance of the type and geographical location of the contractor}

As technology markets evolve, the number of contractors grow and eventually become a specialized autonomous industry (Howells et al., 2004). Unfortunately, little attention has been paid to the type of contractor and their location. The selection of a certain type of contractor is dependent on the supply on the technology market on the one hand (Howells 
et al., 2004), and on the nature of the $R \& D$ project or service that is outsourced on the other.

Agreements with universities are formed whenever risk is not an important obstacle to innovation, and typically serve to share costs. These agreements are found to be complementary to other innovative activities such as performing internal R\&D, sourcing public information and cooperative agreements with suppliers and customers (Veugelers and Cassiman, 2005). Public research organizations and private research centers are partners that provide basic research as well as applied R\&D for direct use. The same applies for polytechnics and other higher education institutes. Cassiman et al. (2005) find that in case project knowledge has high strategic value, internal development or simple contracting of some specific activities is preferred. Projects contracted out to universities show a significantly higher strategic importance. The authors argue that both the governance form and the partner's characteristics may mitigate the risk of leakage. Outsourcing $\mathrm{R} \& \mathrm{D}$ to other firms tends to happen in a more competitive market environment.

Besides the type of contractor, the geographical location of the contractor also needs to be taken into account. The topic of geographical location is related to the aspect of proximity and is found to be important, especially for the decision to outsource core activities (Sorenson et al., 2006; Cusmano et al., 2008). The main argument put forward in favor of local outsourcing is that proximity facilitates (the coordination of) knowledge exchange and trust by enhancing personal contacts (Love and Roper, 2001) which is important to create stable and prolonged relationships for transferring complex knowledge and enhancing innovation (Hansen, 1999; Sorenson et al., 2006). Since knowledge and technology transfer activities are in general localized phenomena (Audretsch and Feldman, 1986; Jaffe, 1986) the regional level is a first appropriate geographical entity to be taken into account.

On the other end, the increasingly global dispersion of R\&D (specialisation) creates a need for firms to access distant knowledge sources and to tap into global networks. This has been facilitated by advances in communication technologies, developments in management and business processes, and the increasing openess of economies (Mol, 2005). Also, expansion (opportunities) in different (especially emerging) markets creates the need 
to adapt $\mathrm{R} \& \mathrm{D}$ to the market strategy of a given host country. In this respect $\mathrm{R} \& \mathrm{D}$ outsourcing is enabled by a large pool of 'local' qualified human capital. Again, the governance and appropriability of the knowledge provided by outsourced R\&D tends to

become more difficult with the complexity of the knowledge transferred (as put forward by the global value chain literature, Gereffi et al., 2005).

Between the local and the global context in which R\&D outsourcing takes place, institutional (including e.g. tax policy, social security) and cultural values and norms can be supposed to play a decisive role in the search process for contractors (Hofstede, 1991; Schwartz, 1999). As such, national specificities remain important.

\subsection{Research questions}

This paper contributes to the debate on $R \& D$ outsourcing in different ways. First, it examines the impact of firm-level decisions with regard to outsourcing of R\&D on the internal R\&D employment intensity. These firm-level decisions take qualitative values: a firm can start with R\&D outsourcing; increase its ongoing outsourcing activities; decrease them; or stop outsourcing.

Secondly, the partners to whom the activities are outsourced are differentiated by type (universities; (semi-) public research centers; other firms) and by geographical location (regional; national (but outside the firm's region); or abroad).

In order to assess the impact of firms' strategies in terms of R\&D outsourcing on changes in the internal employment intensity of R\&D workers, two research questions are formulated:

(i) How do corporate decisions to start, increase, decrease, or stop $R \& D$ outsourcing influence internal R\&D employment intensity?;

(ii) Does the influence on the internal $R \& D$ employment intensity of corporate decisions to start, increase, decrease, or stop $R \& D$ outsourcing vary accross the type and geographical location of the contractor? 


\section{Model and data}

\subsection{The model}

Taking on board the ideas put forward in the literature and based on the research questions, the basic model for the analysis in first differences (except for dummy variables) is as follows:

$$
\begin{aligned}
\Delta R D I_{i t} & =\sum_{t=2}^{T} \alpha_{o t} D_{t}+\sum_{p=2}^{P} \alpha_{p} P_{i}+\sum_{c=1}^{C} \alpha_{1 c} \Delta X_{i c t}+\beta_{0} \Delta R D_{i t}^{S T A R T}+\beta_{1} \Delta R D_{i t}^{I N C R E A S E} \\
& +\beta_{2} \Delta R D_{i t}^{D E C R E A S E}+\beta_{3} \Delta R D_{i t}^{S T O P}+\varepsilon_{i t} \quad \varepsilon_{i t} \sim \mathrm{N}\left(0, \sigma^{2}\right)
\end{aligned}
$$

Note: $i=$ firm; $t=$ year $\left(2001 ; 2003 \text { and 2005); } \Delta \text { denotes first differences (e.g. } \Delta R D I_{i t}=R D I_{i t}-R D I_{i t-1}\right)^{i}$. $D_{t}$ : Year dummies; $P_{i}$ : Dummies denoting the Pavitt group a firm belongs to ( $p=1 \ldots$ : $:$ number of Pavitt categories); $X_{i c t}$ : control variables (see text, $c=1 \ldots C$ : number of control variables).

The internal R\&D employment intensity (RDI) is measured as the ratio of $R \& D$ personnel to total employment, both measured in full time equivalents.

Year dummies $\left(D_{t}\right)$ are included because $R \& D$ intensity tends to change over time depending on general economic conditions (e.g. business cycle). As the basic model is expressed in terms of changes over time, and as detailed information of R\&D data is available only for the odd years (see data discription in section 3.2), three time periods can be considered: 1999-2001; 2001-2003 and 2003-2005. Firms' internal R\&D intensity clearly was on the rise at the beginning of the period under consideration $(+1.3$ percent point between 1999 and 2001 in terms of total business enterprise R\&D personnel per 
thousand employees in industry), sharply fell back in the period 2001-2003, and stagnated in the period 2003-2005 at a level close to the 1999 level (OECD, 2007).

Suggested by the literature review, a number of potential determinants of internal R\&D intensity have been included as control variables. First, cross-sector differences in technological opportunities are captured by dummies denoting the Pavitt category a given firm belongs to $\left(\mathrm{P}_{\mathrm{i}}\right)$. The taxonomy proposed by Pavitt (1984) distinguished five different industry types for the manufacturing sector: science based, scale intensive, labor intensive, resource intensive and specialized suppliers. Tidd et al. (1997) extended the taxonomy to include the services sector, adding an information intensive group as well as specialized suppliers in services.

All other control variables $\left(X_{i c t}\right)$ are continuous and are included in first differences in the estimation, except for group affiliation which is classified by three dummies denoting whether the firm is independent, belongs to a Belgian group or to a foreign group respectively (based on country of origin of the ultimate controller). Average employment is considered for firm size. Other firm characteristics included are exports (average share of turnover realised outside the home country); the share of research expenditures in the total R\&D budget (see e.g. Howells et al., 2008); the ratio of R\&D that is outsourced to total R\&D expenditures; and the share of $R \& D$ personnel in total employment at the beginning of the period under consideration (i.e. $\mathrm{t}-1$ ).

The variables of interest in this paper are those related to firms' decisions to start, increase, decrease or stop outsourcing $R \& D^{\mathrm{ii}}$. These binary choice variables were multiplied by the absolute change in the ratio of outsourced $R \& D$ to total $R \& D$. This allows to consider the magnitude of the changes. As highlighted before, these corporate 
decisions in R\&D outsourcing will be further specified to account for the type of contractor and its geographical location.

\subsection{Data availability and description of the independent and control variables}

The data on Belgian firms used in this analysis are provided by the Federal Cooperation Commission, CFS/STAT, which gathers this information on the basis of the biannual OECD R\&D business survey. The results of four subsequent surveys were taken into account: R\&D survey 2000 (results for 1998 and 1999); R\&D survey 2002 (results for 2000 and 2001); R\&D survey 2004 (results for 2002 and 2003); and R\&D survey 2006 (results for 2004 and 2005). Detailed information on the variable 'outsourced R\&D by type of contractor and geographical location' is only available for the odd years $(1999 ; 2001$; 2003; and 2005). Those years are used in the analysis.

The focus of the survey are enterprises (defined at the level of the smallest legal entity - i.e. those having a VAT number) that perform R\&D on a permanent or quasipermanent base. All firms that are known to perform $R \& D$ are included. An update is made each time a new survey is launched, taking into account both firms known from the past to be $R \& D$ active and a monitoring of firms declaring to be $R \& D$ active, e.g. by means of press releases or demand for R\&D grants (for a more detailed overview see: Commission Coopération Fédérale, 2001). For the analysis in this paper, a permanent or quasipermanent R\&D active firm is any firm which declared in the OECD survey: (i) at least one full time equivalent R\&D employee in at least one year during the period 1999-2005; and (ii) internal $R \& D$ expenditures larger or equal to 30.000 euro in at least one year during the same period. 
During the period 1999-2005 firms went bankrupt, merged, acquired (parts of) other firms or experienced other changes with an important impact on the evolution of R\&D and other enterprise variables. Therefore, information on changes with an impact larger than $10 \%$ (negative or positive) in terms of overall employment or in terms of turnover was asked for in each of the four surveys. In case of mergers, acquisitions or sale of a part of a company, information was collected on other enterprises involved in the operation and the different enterprises involved were taken together as one entity for the entire period. Firms that went bankrupt are excluded from the analysis. This way firm-level data have been constructed to guarantee comparability over time, resulting in a database with 1,971 enterprises as a starting point for the analysis. There are three time cohorts: 1999-2001; 2001-2003; and 2003-2005, and so 5,913 potential observations. Unfortunately, due to the voluntary nature of the survey there are a lot of missing values. More information is available for key variables on internal $R \& D$ activities and for $R \& D$ personnel since an additional short survey/telephone follow-up and other sources were used to gather these data. Data on the evolution of outsourced $R \& D$ expenditures was available for 1,378 observations. However, in order to estimate the model as described in section 3.1, only 1,161 observations for 761 enterprises could be taken into account for a model not differentiating between type (firms outside the group - universities - public and private research centers) and geographical location (regional - national - abroad) of the contractor. Including the latter distinction, the need for more detailed information on outsourcing R\&D left a dataset of 553 observations for 384 enterprises.

$<$ Insert Figure 1 about here> 
The comparison in Table 1 of the observations (for the total of the three time periods) included in the analysis with the ones pertaining to the the population of (quasi-) permanent R\&D active enterprises in Belgium but not included in the analysis, reveals a selection bias towards large, less export-oriented, and more R\&D intensive enterprises. However, these firms have a lower share of outsourced $R \& D$ in the total (internal and outsourced) R\&D budget. The findings seem to support the negative relation between outsourcing and firm size found by Coase (1937) but contrast the findings of Laursen and Salter (2006) for innovative activities. In terms of change in R\&D employment intensity (the dependent variable in the analysis in section 4) no significant differences are found between both groups of observations.

Table 1: Mean values of the independent and the continuous control variables for observations included in the analysis (basic model - see Figure 1) and those not included

\begin{tabular}{|l|c|c|c|}
\hline & Panel & $\begin{array}{c}\text { Population } \\
\text { (excl. panel) } \\
\text { observations }\end{array}$ & Sig.* \\
\hline $\begin{array}{l}\text { Change in R\&D employment intensity (R\&D } \\
\text { employment/average employment) }\end{array}$ & $-0.02(1,161)$ & $-0.03(936)$ & $>.10$ \\
\hline Size (average employment) & $320.89(1,156)$ & $171.69(4,400)$ & $<.01$ \\
\hline Export (share of turnover outside the home country) & $0.43(925)$ & $0.53(1,441)$ & $<.01$ \\
\hline $\begin{array}{l}\text { Research share (share of research in total R\&D budget) } \\
\text { R\&D intensity }\end{array}$ & $0.41(871)$ & $0.38(1,095)$ & $<.10$ \\
\hline $\begin{array}{l}\text { Outsourced R\&D (share of outsourced R\&D budget in } \\
\text { total - internal + outsourced }- \text { R\&D budget) }\end{array}$ & $0.13(1,161)$ & $0.16(1,867)$ & $<.01$ \\
\hline
\end{tabular}


Note: number of observations in brackets. The number of observations for some variables in the panel can be lower than 1,161 because the analysis in section 4 is based on a general-to-specific approach in which nonsignificant variables are gradually dropped. * Significance of the difference between the averages of the two groups of observations based on a t-test.

Comparison of the distribution of firm ownership in the selected group of 1,161 observations (independent firms: $31.2 \%$; firms belonging to a Belgian group: $31.3 \%$; firms belonging to an international group: $37.6 \%$ ) with the one for observations not included (respectively $39.5 \% ; 29.1 \%$ and $31.4 \%$ ) indicates that observations for firms belonging to a (especially international) group are overrepresented in the analysis. In terms of industrial activity, a comparison of the analyzed group with the group of observations not taken into account reveals no systematic changes for the Pavitt categories information intensive, scale intensive, science based, resource intensive or labour intensive. However, a big discrepancy exists between specialized suppliers in services and manufacturing. In the manufacturing sector, firms belonging to this category were largely overrepresented in the group of observations taken into account for the analysis (18.9\% of observations in the analysed group versus $13.8 \%$ for those not analysed). The opposite was true in services $(9.3 \%$ versus $14.9 \%)$

A comparison of the 553 observations containing information on the type and geographical location of the contractor with the 1,161 observations included in the basic model revealed no significant bias in terms of the control variables presented in Table1.

\section{Analysis}




\subsection{Descriptive statistics on firm decisions in terms of outsourcing of $R \& D$}

On average, over the period 1999-2005, a firm's outsourced R\&D budget amounts to 13.1 $\%$ (standard deviation 0.23 ) of the total (internal and outsourced) R\&D budget. Decisions to start, increase, decrease, or stop outsourcing imply absolute changes in the share of outsourced $\mathrm{R} \& \mathrm{D}$ in total R\&D of respectively +0.28 (standard deviation equals 0.28 ); $+0.14(0.19) ;-0.18(0.20)$; and $-0.28(0.25)$. As such, the share of outsourced R\&D involved in starting and stopping outsourcing R\&D seems of equal importance, whereas the change in the share in the total $\mathrm{R} \& \mathrm{D}$ budget is larger on average in case of a decrease than in case of an increase in outsourcing.

Table 2 highlights the frequencies of the different outsourcing decisions by headoffice, by size class (large refers to firms with 250 or more employees; medium-sized to 50-249; and small to less than 50), and by industrial activity. In terms of ultimate control of the firm it can be noted that firms belonging to a group are relatively more frequently involved in sustained outsourcing and less in starting and especially stopping such activities. Also, less than one third of these firms were not at all engaged in outsourcing R\&D in two consecutive time periods (1999-2001; 2001-2003; 2003-2005). Independent firms relatively most often take the decision to stop the outsourcing of $R \& D$ and are less likely to be engaged in outsourcing of R\&D.

Table 2: Frequency of decisions to outsource R\&D broken down by head office; size and industrial activity - in row percentages

$\begin{array}{lllll}\text { Start } & \text { Decrease } & \text { Stop Null Number of }\end{array}$




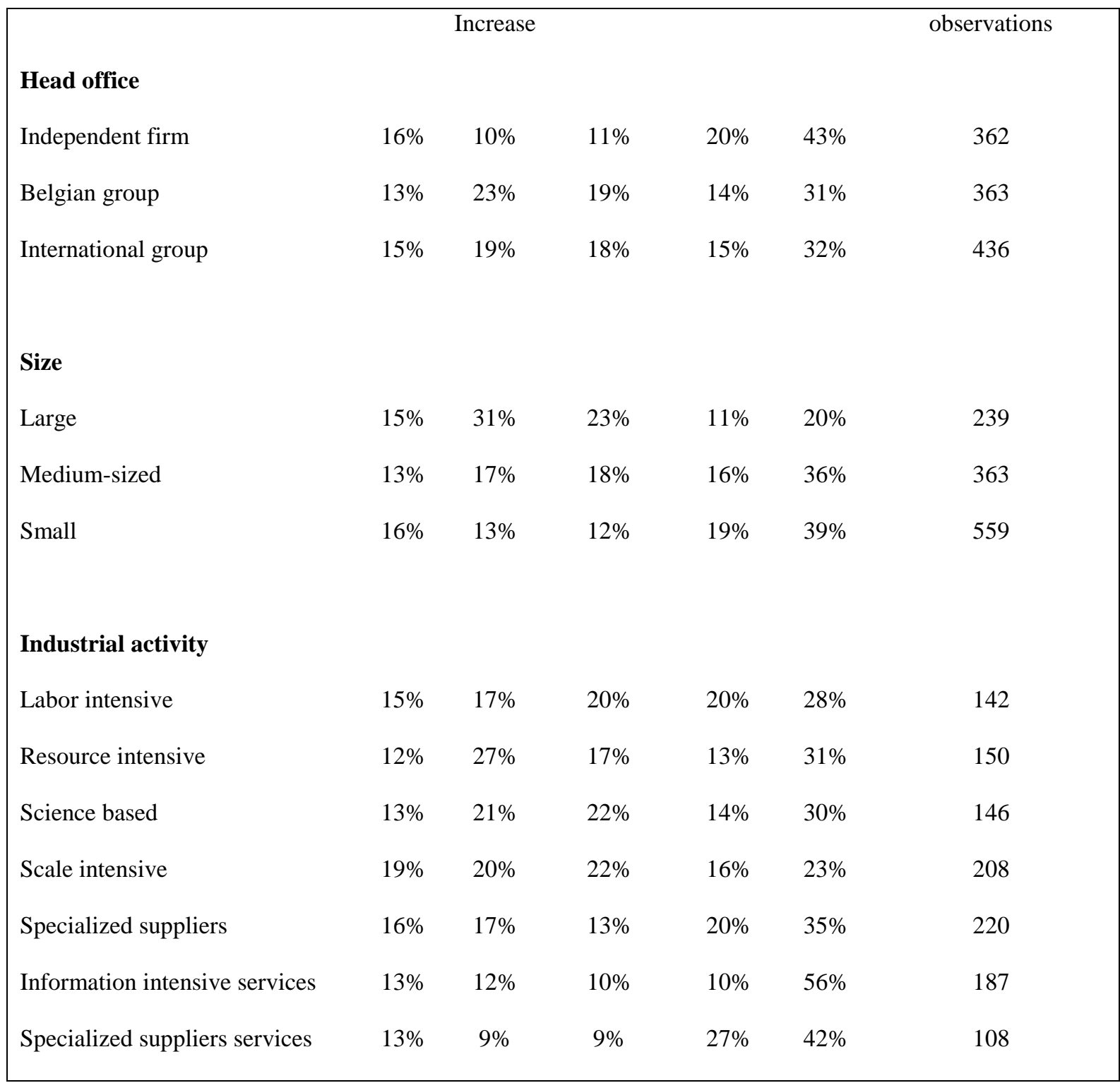

Note: The first five columns show row percentages, the last column shows the number of observations (total number of observations is 1,161$)$.

The propensity to increase or decrease existing R\&D outsourcing increases with firm size. The opposite is true for decisions to start or stop outsourcing R\&D. These findings are in line with those presented by Veugelers and Cassiman (1999) indicating that large resourceful firms have a higher propensity to combine internal and outsourced R\&D than their counterparts. 
Finally, concerning industrial activity (Pavitt taxonomy) a clear distinction can be made between manufacturing and services firms. Close to $40 \%$ of firms in the manufacturing sector are involved in sustained (increased or decreased) outsourcing of R\&D (with specialized suppliers at the lower end) compared to half as much in the services sector. For information intensive services and specialized suppliers services this is the case only for about one fifth of the firms. The findings corroborate Laursen and Salter (2006) who found knowledge intensive small firms less likely to be open because they are often based on the exploitation of a new idea and face a larger danger of leakage of their ideas. Therefore, they limit the nature and scope of their external interaction.

Table 3 presents the correlations between the different types and geographical locations of the R\&D contractor. The results presented refer to the sample of 553 observations included in the detailed model (see Figure 1). Before investigating the correlation between outsourcing decisions with certain types of contractors at certain geographical locations, a snapshot is given on the number of contractors involved in each of these decisions (start; increase; decrease; or stop) respectively by type and by geographical location of the contractor. An analysis at the level of the detailed model (see Figure $1-553$ observations) for combined location and type of contractor revealed no significant differences (at 5\% level) in terms of the four possible firm decisions related to R\&D outsourcing between the observations included in the analysis and those pertaining to the basic model (Figure 1-1,161 observations).

Firms starting to outsource do so in $43 \%$ of the cases to another firm, in $49 \%$ of the cases to a university and in $35 \%$ to a research center. For increased outsourcing this amounts to respectively $63 \%$; $69 \%$; and $68 \%$. For decreased outsourcing this amounts to 
respectively $71 \%$; $73 \%$; and $55 \%$. For stopping it is respectively $58 \%$; $51 \%$; and $34 \%$. These data reveal that started and sustained outsourcing is relatively more likely to involve universities. Also, increased outsourcing occurs relatively more frequently in case of outsourcing to a research center, whereas stopping most often involves other firms. This could be explained by the fact that associations with contract research firms or other technical service providers generally are well-delineated contractual agreements used to fulfill very specific needs in a relatively short-time period. Outsourcing to universities in many cases is part of a firm's long-term strategy to manage its pipeline of innovation.

In terms of geographical distribution, to start outsourcing clearly most often includes regional contractors (77\%), followed by foreign (24\%) and national (15\%) ones. Increased (respectively decreased) outsourcing involves 93\% (94\%) regional contractors, followed by $65 \%$ (56\%) foreign and $41 \%$ (39\%) national. The corresponding percentages for firms deciding to stop outsourcing are $82 \% ; 37 \%$; and $12 \%$.

The data presented above show that management decisions in terms of starting, increasing, decreasing, or stopping to outsource $R \& D$ occur at the same time with different types of contractors (confirming the findings by Howells et al., 2004) and at different locations. On average, firms starting to outsource R\&D do so with 1.27 different types of contractors at 1.16 different locations. For increased and decreased outsourcing this amounts to respectively 2.01 and 2.00 types at 2.00 and 1.89 locations. In case a firm decides to stop R\&D outsourcing, on average, 1.43 different types of contractors at 1.31 different locations are involved. The information presented in Table 3 reveals important correlations between certain types of contractors at certain locations. 
Table 3: Firms' decisions on R\&D outsourcing: Correlation between type and geographical location of the contractor

\begin{tabular}{|c|c|c|c|c|c|c|c|c|c|c|}
\hline & & 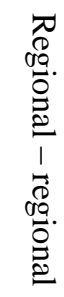 & 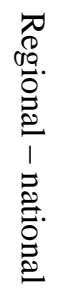 & 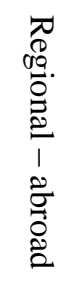 & 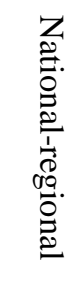 & 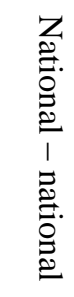 & 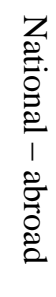 & 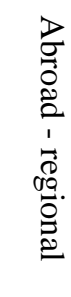 & 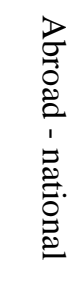 & $\begin{array}{l}\mathbb{Z} \\
0 \\
0 \\
0 \\
1 \\
\tilde{0} \\
0 \\
0 \\
0\end{array}$ \\
\hline \multirow{6}{*}{ } & Firm - firm & n.a. & & & red. & n.a. & & red. & red. & n.a. \\
\hline & Firm - university & & & & & & & & & ++ \\
\hline & Firm - center & & & & & & & & & \\
\hline & University - university & n.a. & & & red. & n.a. & & red. & red. & n.a. \\
\hline & University- center & & + & & & ++ & + & & & \\
\hline & Center - center & n.a. & & ++ & red. & n.a. & & red. & red. & n.a. \\
\hline
\end{tabular}

\begin{tabular}{|l|l|c|c|c|c|c|c|c|c|c|}
\hline \multirow{3}{*}{} & Firm - firm & n.a. & +++ & +++ & red. & n.a. & ++ & red. & red. & n.a. \\
\cline { 2 - 12 } & Firm - university & & & + & & ++ & & ++ & & \\
\cline { 2 - 11 } & Firm - center & & & & & & & & & \\
\cline { 2 - 12 } & University - university & n.a. & +++ & +++ & red. & n.a. & +++ & red. & red. & n.a. \\
\cline { 2 - 12 } & University- center & & & +++ & & +++ & +++ & + & +++ & +++ \\
\cline { 2 - 12 } & Center - center & n.a. & ++ & & red. & n.a. & +++ & red. & red. & n.a. \\
\hline
\end{tabular}

\begin{tabular}{|l|l|c|c|c|c|c|c|c|c|c|}
\hline \multirow{3}{*}{} & Firm - firm & n.a. & ++ & ++ & red. & n.a. & ++ & red. & red. & n.a. \\
\cline { 2 - 11 } & Firm - university & & & & & + & & & + & + \\
\cline { 2 - 10 } & Firm - center & & & +++ & & + & & + & & \\
\cline { 2 - 9 } & University - university & n.a. & ++ & +++ & red. & n.a. & +++ & red. & red. & n.a. \\
\cline { 2 - 12 } & University- center & & & & +++ & +++ & & +++ & +++ & +++ \\
\cline { 2 - 11 } & Center - center & n.a. & & + & red. & n.a. & & red. & red. & n.a. \\
\hline
\end{tabular}

\begin{tabular}{|c|l|c|c|c|c|c|c|c|c|c|}
\hline \multirow{5}{*}{} & Firm - firm & n.a. & & & red. & n.a. & +++ & red. & red. & n.a. \\
\cline { 2 - 11 } & Firm - university & & & & & & & & & \\
\cline { 2 - 11 } & Firm - center & & & & & & & & & \\
\cline { 2 - 12 } & University - university & n.a. & ++ & & red. & n.a. & ++ & red. & red. & n.a. \\
\cline { 2 - 12 } & University- center & & & ++ & ++ & +++ & +++ & & & \\
\cline { 2 - 11 } & Center - center & n.a. & & ++ & red. & n.a. & ++ & red. & red. & n.a. \\
\hline
\end{tabular}

Note: Correlations for the detailed model (see figure 1) with 553 observations. Correlation is statistically significant at $10 \%(+/-), 5 \%(++/--), 1 \%(+++/---)$. n.a.: not applicable because no identification possible of contractor(s) involved. Red.: redundant with information presented in another cell. 
In Table 3 a distinction is made between firms' decisions to start; increase; decrease; or stop R\&D outsourcing. The second column gives all combinations of possible types of contractors and the first row does the same for possible locations of the contractor. The first location refers to the location of the first mentioned contractor in column 2, whereas the second one refers to the location of the second type of contractor mentioned in column 2. For example, the cell on the second row in the third column indicates the correlation between a firm's decision to start outsourcing R\&D to a regional firm on the one hand, and to a regional university on the other hand.

For firms deciding to start outsourcing $\mathrm{R} \& \mathrm{D}$, a positive correlation is found between regional (respectively national) universities and national research centers; between national universities and world research centers, and between regional and foreign research centers. Also, for contractors located abroad, a positive correlation is found between decisions to start outsourcing to firms on the one hand and to universities on the other hand. These correlations suggest that firms deciding to start outsourcing R\&D carefully choose a mix of partners in function of directly applicable research (including other firms' expertise or the expertise of research centers).

For sustained outsourcing, a larger number of more significant correlations is found. This is not surprising given that the average number of contractors in these activities is higher (see before). Compared to start outsourcing R\&D, firms' decisions to increase or decrease R\&D oustsourcing involve a combination of regional, national, and abroad located firms. A similar remark can be made for universities. Together with the involvement of research centers at different locations, this contributes to a broad mixture of 
contractors. An important difference between the case in which a firm decides to increase R\&D outsourcing compared to decreasing R\&D outsourcing seems to be the absence of correlation between outsourcing to firms and outsourcing to research centers (at different combinations of geographical levels) in case of increased outsourcing. This could point to a more prominent role of the involvement of research centers at the time the decision to start outsourcing is taken.

Stopping to outsource R\&D with national firms is strongly correlated with stopping with foreign firms. The same is true for research centers and universities (for which this relation also holds between the regional and the national level). Also, a high correlation exists between stopping outsourcing with universities on the one hand and with research centers on the other.

\subsection{Estimation}

The model presented in section 3.1 is estimated using pooled OLS. The reason to perform pooled OLS is twofold. First, all variables are considered in first differences, except for the dummy variables (year dummies; Pavitt categories; and group affiliation). As a specification in first differences is considered, time invariant firm-specific effects (fixed effects) are differenced out. Second, a fixed effects estimation is troublesome given the small number of firms for which observations for more than one year is available.

Estimation results are reported in Table 4. As the value of the dependent variable ranges from -1 to +1 it was transformed to apply a logit specification ${ }^{\text {iii }}$. Column (i) shows the results of the basic model of firms' decisions on R\&D outsourcing and column(ii) 
reports the results of the detailed specification, in which the decision with respect to outsourcing $\mathrm{R} \& \mathrm{D}$ is broken down by the type of contractor and its location (i.e. both interacted). The two models presented are the final result of a general-to-specific approach, in which the most general unrestricted model is gradually simplified by dropping nonsignificant variables, as long as specification tests are satisfied (see e.g. Charemza and Deadman, 1992). One of the advantages of a general-to-specific approach is that the number of observations can increase when non-significant variables for which missing values occur can be dropped. Moreover, the quality of the specification often improves considerably by dropping irrelevant variables. The non-significant variables that remain in the specific models could not be dropped due to the significance of Ramsey's RESET test (a test of misspecification). All models include unreported year dummies that are not statistically significant.

Table 4: R\&D employment intensity and outsourcing

\begin{tabular}{|c|c|c|}
\hline $\begin{array}{c}\text { Dependent variable }=\text { Change in internal R\&D } \\
\text { employment intensity }\end{array}$ & (i) \\
\hline & Basic model & Full model with interaction \\
\hline Pavitt: Labor intensive & $-0.06(0.01)^{* * *}$ & $-0.10(0.00)^{* * *}$ \\
\hline Pavitt: Science based & $0.11(0.01)^{* * *}$ & $0.11(0.15)$ \\
\hline Pavitt: Information intensive services & $0.05(0.21)$ & $-0.05(0.08)^{*}$ \\
\hline Pavitt: Resource intensive & & $-0.07(0.70)$ \\
\hline Share of research expenditures in total R\&D expenditures & & $0.04(0.40)$ \\
\hline R\&D intensity beginning of period & $-0.61(0.00)^{* * *}$ & $-0.60(0.00)^{* * *}$ \\
\hline Share of outsourced R\&D in total R\&D budget & $0.06(0.12)$ & $-0.38(0.10)^{*}$ \\
\hline Change in outsourced R\&D - start & $-0.17(0.02)^{* *}$ & \\
\hline Other firm within the region & & \\
\hline
\end{tabular}




\begin{tabular}{|c|c|c|}
\hline Research center within the nation & & $-0.77(0.06)^{*}$ \\
\hline Change in outsourced R\&D - increase & $-0.31(0.00)^{* * *}$ & $1.32(0.04)^{* *}$ \\
\hline Other firm abroad & & $1.92(0.10)^{*}$ \\
\hline University abroad & & $-0.80(0.07)^{*}$ \\
\hline Research center within the region & & $2.26(0.02)^{* *}$ \\
\hline Change in outsourced R\&D - decrease & & $-29.32(0.02)^{* *}$ \\
\hline University within the nation & & $0.35(0.05)^{* *}$ \\
\hline Change in outsourced R\&D - stop & & 0.19 \\
\hline Other firm within the nation & & 553 \\
\hline Adjusted R-squared & 1,161 & \\
\hline N & & \\
\hline
\end{tabular}

Note: Standard errors are heteroskedastic-consistent; p-value in brackets; * (**): Statistically significant at $5 \%,(1 \%) .{ }^{\circ}$ Interaction refers to the interaction between type of contractor and geographical location.

In the basic model (column i), the dummies denoting the Pavitt group a firm belongs to, indicate that labor intensive firms witnessed a significantly lower increase in internal R\&D employment intensity relative to the reference group (specialized suppliers) whereas science based firms had significantly higher growth in internal R\&D employment intensity, again compared to the reference group. Also, internal R\&D employment intensity at the beginning of the period under consideration is statistically significant. ${ }^{\text {iv }}$ The negative sign indicates that firms with an initially high internal R\&D employment intensity are - all other things equal - more likely to witness a larger decrease (smaller increase) in $R \& D$ employment intensity in the following two-year period than their counterparts. The other control variables do not turn out to be statistically significant ${ }^{\mathrm{v}}$.

The decision of firms to start or to increase R\&D outsourcing turns out to have a statistically significant negative impact on internal R\&D employment intensity. No 
significant impact on internal $\mathrm{R} \& \mathrm{D}$ employment is found for firms deciding to decrease or to stop R\&D outsourcing.

Refining the outsourcing variables, using a breakdown of both the type of partner and its location (column ii) does not change the conclusions with respect to control variables, except for the statistical significance (10\%) of the negative sign of resource intensive firms (Pavitt taxonomy). However, the estimation clearly shows that overall decisions to start, increase, decrease or stop the outsourcing of $R \& D$ conceal important differences between types and geographical location of the R\&D contractor as to the impact on internal $R \& D$ employment intensity. This could be related to the different motives underlying the corporate decision to outsource $R \& D$ according to the type and geographical location of the R\&D contractor and is in line with the correlations found in Table 3.

The decision to start outsourcing $R \& D$ to firms within the proper region and to research centers in another region has a significant negative impact - though only at the $10 \%$ level - on internal R\&D employment intensity, suggesting a substitution effect.

The coefficients of increased outsourcing towards other firms and universities outside the country are significant. The positive sign now suggests a complementary relationship with firms' own R\&D intensity. On the other hand, the significant negative sign of increased $R \& D$ outsourcing towards research centers in the proper region suggests substitution for internal R\&D employment.

In contrast with the lack of statistical evidence of an impact in the basic model of firms' decisions to decrease or stop R\&D outsourcing, taking into account the type and geographical location of the contractor reveals that decreasing $R \& D$ outsourcing towards 
universities in another Belgian region and stopping to outsource to a university in the proper region have a statistically significant positive impact on the internal $\mathrm{R} \& \mathrm{D}$ employment intensity of firms. The opposite is true in case of firms' decisions to cease to outsource R\&D to other firms in another Belgian region. This decision has a significant and highly negative impact on internal R\&D employment intensity suggesting that when outsourcing $R \& D$ towards these contractors stops internal $R \& D$ employment intensity decreases.

\section{Conclusions}

This paper explored the effects of R\&D outsourcing on the R\&D labor composition. Its aim was to assess if firms' R\&D outsourcing strategies changed in internal R\&D employment intensity. A distinction was made between firms' decisions to start; increase; decrease; or stop R\&D outsourcing. Differences in the type and location of the R\&D contractor have also been considered.

In terms of $R \& D$ outsourcing activities, the analysis revealed that larger firms and firms belonging to a group have a higher propensity to be engaged in $R \& D$ outsourcing in a more permanent way. Smaller firms have a relatively higher propensity to start or to stop R\&D outsourcing. Also, management decisions in terms of starting, sustaining or stopping R\&D outsourcing occur at the same time with different types of contractors at different locations. Firms' decisions to start or to stop R\&D outsourcing more frequently involve regional contractors, whereas sustained outsourcing relatively more frequently involves national and international contractors. Finally, the outcomes of the analysis pointed to a careful choice of a mix of different types of contractors at different geographical locations. 
In this respect, decisions to start or to stop $R \& D$ outsourcing frequently involve both universities and research centers. Sustained outsourcing more often is a mixture of both public and private contractors.

In terms of the effects of decisions related to the outsourcing of $\mathrm{R} \& \mathrm{D}$, started or increased outsourcing - at least in the short run - has a significant negative effect on the internal $R \& D$ employment intensity, pointing to a change in labor composition. No significant impact is found in case a firm decides to decrease or to stop R\&D outsourcing. This indicates that decreases in internal R\&D employment intensity related to started and increased $\mathrm{R} \& \mathrm{D}$ outsourcing are not turned around at the time outsourcing stops or decreases. However, these decisions conceal marked differences between types and geographical locations of the R\&D contractor. Increased outsourcing towards other firms and universities outside the country affects internal R\&D employment intensity in a significant positive way. The opposite is true in case of outsourcing towards research centers in the proper region.

These findings are not without policy relevance. The finding that starting or increasing $R \& D$ outsourcing negatively affects the internal $R \& D$ employment intensity could stir fear of hollowing out the local knowledge base. This fear however seems to be unjustified as these negative findings seem to be mainly related to the outsourcing of more applied - R\&D towards local research centers and there actually seem to be positive effects of increased R\&D outsourcing towards other firms and universities outside the country, suggesting the existence of positive international spillovers.

Finally, given a number of (data) limitations of the present analysis, the results presented in this paper should be considered with some caution. First, the analysis is based 
on a panel of (quasi-)permanent R\&D active firms in Belgium for the period 1999-2005. It cannot be excluded that the analytical outcomes are somewhat biased towards large firms; research intensive firms active in the specialized suppliers manufacturing industry; and firms belonging to an international group.

Second, no data are available on the determinants of outsourcing and concerns of appropriability which are very likely to interact with the decision to start; increase; decrease; or stop outsourcing and its impact on internal R\&D employment.

Finally, due to a lack of information, the type of R\&D activities outsourced (e.g. basic or applied research, product or process development) or the continuance of outsourcing to the same entity could not be taken into account in the analysis.

\section{References}

Antras, P. (2005), 'Incomplete Contracts and the Product Cycle', American Economic Review, 95, 1054-1073.

Arrow, K. (1962), 'Economic welfare and the allocation of resources for invention', in: R. Nelson (Ed.), The Rate and Direction of Inventive Activity, Princeton University Press: Princeton.

Audretsch, D., Feldman, M. (1986), 'R\&D Spillovers and the Geography of Innovation and Production', American Economic Review, 86, 630-640.

Audretsch, D., Menkveld, A., Thurik, R. (1996), 'The decision between internal and external R\&D', Journal of Institutional and Theoretical Economics, 152, 519-530. 
Belderbos, R., Carree, M., Diederen, B., Lokshin, B., Veugelers, R. (2004), 'Heterogeneity in R\&D cooperation strategies', International Journal of Industrial Organization, 22, 1237-1263.

Beneito, P. (2006), 'The innovative performance of in-house and contracted R\&D in terms of patents and utility models', Research Policy, 35, 502-517.

Bönte, W. (2003), 'R\&D and productivity: internal vs. external R\&D - evidence from West German manufacturing industries', Economics of Innovation and New Technology, 12, 343-360.

Brusoni, S. Prencipe, A., Pavitt, K. (2001), 'Knowledge specialization, organizational coupling, and boundaries of the firm: why do firms know more than they make?', Administrative Science Quarterly, 46, 597-621.

Cassiman, B., Di Guardo, C., Valentini, G. (2005). 'Organizing for Innovation: R\&D Projects, Activities and Partners', IESE Business School Working Paper No. 597.

Cassiman, B., Veugelers, R. (2006), 'In search of complementarity in innovation strategy: Internal R\&D, cooperation in R\&D and external technology acquisition', Management Science, 52, 68-82.

Charemza, W.W., D.F. Deadman, D.F. (1997), New Directions in Econometric Practice: General to Specific Modelling, Cointegration and Vector Autoregression.(Second Edition) Edward Elgar: Cheltenham.

Chesbrough, H. (2003), Open Innovation: The New Imperative for Creating and Profiting from Technology, Harvard Business School Press, Boston, Massachusetts.

Cohen, W., Levinthal, D. (1990), 'Absorptive capacity: a new perspective of innovation and learning', Administrative Science Quarterly, 35, 128-152. 
Commission Coopération fédérale, Groupe de concertation, Groupe ad hoc Profit (2001), Méthodologie pour l'estimation de l'effort de $R \& D$ des entreprises. Rapport interne SSTC: Brussels.

Coombs, R. (1996), 'Core competencies and the strategic management of R\&D', $R \& D$ Management, 25, 345-355.

Coombs, R., Harvey, M., Metcalfe, S. (2003), 'Analysing distributed processes of provision and innovation', Industrial and Corporate Change, 12, 1125-1155.

Cusmano L., Luisa, M., Morrison, A. (2008), 'Innovation and the geographical and functional dimensions of outsourcing: An empirical investigation based on Italian firm level data', Papers in Evolutionary Economic Geography, $2008 \mathrm{n}^{\circ} 6$, Utrecht University, Section of Economic Geography.

Davidson, W., McFetridge, D. (1984), 'International Technology Transactions and the Theory of the Firm', Journal of Industrial Economics, 32, 253-264.

Edler, J., Meyer-Krahmer, F., Reger, G. (2002), 'Changes in the strategic management of technology: results of a global benchmarking study', $R \& D$ Management, 32, 149-164.

Gereffi, G, Humphrey, J., Sturgeon, T. (2005), 'The governance of global value chains', Review of International Political Economy, 12(1), 78-104.

Gilley, K. and Rasheed, A. (2000), 'Making More by Doing Less: An Analysis of Outsourcing and its Effects on Firm Performance', Journal of Management, 26 (4), $763-790$.

Granstrand, O., Bohlin, E., Oskarson, C., Sjöberg, N. (1992), 'External technology acquisition in large multitechnology corporations', $R \& D$ Management, 22, 111-113. 
Griffith, R., Redding, S., Van Reenen, J. (2004), 'Mapping The Two Faces Of R\&D: Productivity Growth In A Panel Of OECD Industries', Review of Economics and Statistics, 86, 883-895.

Hamel, G., Doz, Y., and Prahalad, C. (1989) 'Collaborate with Your Competitors and Win', Harvard Business Review, 67, 133-139.

Hofstede, G. (1991), Cultures and organizations: Software of the mind. McGraw-Hill: Berkshire.

Holmström, B., Milgrom, P. (1994), 'The Firm as an Incentive System', American Economic Review, 84, 972-991.

Howells, J., Gagliardi, D., Malik, K. (2008), 'The growth and management of R\&D outsourcing: evidence from UK pharmaceuticals', $R \& D$ Management, 38, 205-219.

Howells, J., James, A., Malik, K. (2004), 'Sourcing external technological knowledge: a decision support framework for firms', International Journal of Technology Management, 27, 143-155.

Jacobides, M., Billinger, S., (2006), 'Designing the boundaries of the firm: From "make, buy or ally" to the dynamic benefits of vertical architecture', Organization Science, 17 (2), 249-261.

Jaffe, A. (1986), 'Technological Opportunity and Spillovers of R\&D: Evidence from Firms' Patents, Profits and Market Value', American Economic Review, 76, 984-1001.

Kahn, S. (2000), The bottom-line impact of nonstandard jobs on companies' profitability and productivity, in F. Carré, M. A. Ferber, L. Golden, and S. A. Herzenberg (Eds.), Nonstandard work: The nature and challenges of changing employment relations (pp. 235-265). Urbana-Champaign: University of Illinois. 
Klevorick, A., Levin, R., Nelson, R., Winter, S. (1995), 'On the sources and significance of interindustry differences in technological opportunities', Research Policy, 24, 185205.

Kogut, B., Zander, U. (1993), 'Knowledge of the firm and the evolutionary theory of the multinational corporation', Journal of International Business Studies, 24, 625-645.

Laursen, K., Salter, A. (2006), 'Open for Innovation: The role of openness in explaining innovative performance among UK manufacturing firms', Strategic Management Journal, 27, 131-150.

Love J.H. and S. Roper 2001, Outsourcing in the innovation process: Locational and strategic determinants, Papers in Regional Science, 80 (3), 317-336.

Mansfield, E., Romeo, A. (1980), 'Technology Transfer to Overseas Subsidiaries by U.S.Based Firms', Quarterly Journal of Economics, 95, 737-750.

Mehta, S. and Peters, L. (2007), 'Outsourcing a Core Competency', Research and Technology Management, 50(3), 26-34.

Mol M.J. 2005, 'Does being R\&D intensive still discourage outsourcing? Evidence from Dutch manufacturing', Research Policy, 34, 571-582.

Narula, R. (2001), 'Choosing between internal and non-internal R\&D activities: some technological and economic factors', Technology Analysis and Strategic Management, $13,365-387$.

OECD (2002), The measurement of scientific and technological activities: Frascati manual: proposed standard practice for surveys on research and experimental development. OECD: Paris.

OECD (2007), Main Science and Technology Indicators. OECD: Paris. 
Pavitt, K. (1984), 'Sectoral patterns of technological change: towards a taxonomy and a theory', Research Policy, 13, 343-373.

Pianta, M. (2004), 'The impact of innovation on jobs, skills and wages', Economia e Lavoro, 1, 7-26.

Piga, C., Vivarelli, M. (2004), 'Internal and external R\&D: a sample selection approach', Oxford Bulletin of Economics and Statistics, 66, 457-482.

Pisano, G. (1990), 'The R\&D boundaries of the firm: an empirical analysis', Administrative Science Quarterly, 35, 153-176.

Piva, M., Santarelli, E., and Vivarelli, M. (2003), 'The Skill Bias Effect of Technological and Organisational Change: Evidence and Policy Implications', IZA Discussion Papers 934, Institute for the Study of Labor (IZA).

Quinn, J.B. (2000), 'Outsourcing Innovation: the New Engine of Growth', Sloan Management Review, 41, 13-28.

Quinn, J.B. and Hilmer F.G. (1995), 'Make versus buy: strategic outsourcing', McKinsey Quarterly, 1, 48-70.

Rosenberg, N. (1990), 'Why Do Firms Do Basic Research (with Their Own Money)?', Research Policy, 19, 165-174.

Schwartz, S. (1999), 'A Theory of Cultural Values and Some Implications for Work', Applied Psychology: An International Review, 48, 23-47.

Sorenson, O., Rivkin J.W. and L. Fleming, 2006, 'Complexity, networks and knowledge flow', Research Policy, 35, 994-1017.

Swan, K. and Allred, B. (2003), 'A product and process model of the technology-sourcing decision', Journal for Product and Innovation Management, 20(6), 485-497. 
Tarabusi, C., (1997), 'Technology and Employment: the Role of Organisational Change and Learning', STI Review 20, OECD, Paris.

Teece, D. (1986), 'Profiting from technological innovation: implications for integration, collaboration, licensing and public policy', Research Policy, 15(6), 285-305.

Teece, D.J., Pisano, G. and Shuen, A. (1997), Dynamic capabilities and strategic management', Strategic Management Journal 18 (7), 509-533.

Teirlinck, P., Spithoven, A. (2008), 'The spatial organization of innovation: open innovation, external knowledge relations and urban structure', Regional Studies, 42, $689-704$

Tether, B. (2002), 'Who co-operates for innovation, and why. An empirical analysis', Research Policy, 31, 947-967.

Tidd, J., Bessant, J., Pavitt, K. (1997), Integrating Technological, Market and Organisational Change. John Wiley and Sons Ltd.: Chichester.

Tiwana, A., Keil, M. (2007), 'Does Peripheral Knowledge Complement Control? An Empricial Test in Technology Outsourcing Alliances', Strategic Management Journal, 28, 623-634.

Trefler, D. (2005), 'Offshoring: threats and opportunities', in: S. Collins, L. Brainard (Eds), Offshoring White-Collar Work-The Issues and the Implications. Brookings Institution Press, New York .

Tushman, M. and Anderson, Ph. (1997), Managing Strategic Innovation and Change: A Collection of Readings, Oxford University Press, Oxford.

Veugelers, R., Cassiman, B. (1999), 'Make and buy in innovation strategies: evidence from Belgian manufacturing firms', Research Policy, 28, 63-80. 
Veugelers, R., Cassiman, B. (2005), 'R\&D cooperation between firms and universities. Some empirical evidence from Belgian manufacturing', International Journal of Industrial Organization, 23, 355-379.

von Hippel, E. (1988), The Sources of Innovation. Oxford University Press: New York. Williamson O. E. (1985), The Economic Institutions of Capitalism, Free Press, New York. Williamson, O. (1975), Markets and Hierarchies: Analysis and Antitrust Implications. Free Press: New York.

Wilson, R. (1977), 'The Effects of Technological Environment and Product Rivalry on R\&D Efforts and Licensing of Inventions', Review of Economics and Statistics, 59, $171-78$.

Wuyts, S., Colombo, M.G., Dutta, S., Nooteboom, B. (2005), 'Empirical tests of optimal cognitive distance', Journal of Economic Behavior and Organization, 58, 277-302.

\footnotetext{
${ }^{\mathrm{i}}$ Data on R\&D outsourcing is only available for odd years. Therefore, first differences consider the difference of a variable for a given year and its value two years before.

ii $\operatorname{Start}_{\mathrm{i}, \mathrm{t}}=1$ if (Outsourced $\left.R \& D_{\mathrm{i}, \mathrm{t}-1}=0\right)$ and (Outsourced $\left.R \& D_{\mathrm{i}, \mathrm{t}}>0\right)$; Increase $_{\mathrm{i}, \mathrm{t}}=1$ if $0<$ Outsourced $R \& D_{i, t-1}<$ Outsourced $R \& D_{i, t} ;$ Decrease $_{i, t}=1$ if Outsourced $R \& D_{i, t-1}>$ Outsourced $R \& D_{i, t}>0$; Stop $p_{i, t}=1$ if (Outsourced $\left.R \& D_{i, t-1}=1\right)$ and (Outsourced $\left.R \& D_{i, t}=0\right)$; Null $l_{i, t}=1$ if (Outsourced $R \& D_{i, t-1}=0$ ) and (Outsourced $\left.R \& D_{i, t}=0\right)$.

iii Estimation with the dependent variable not transformed, provides similar results and does not change the main conclusions.

iv The inclusion of a lagged dependent variable could bias the results if the error term is subject to autocorrelation. Unfortunately the number of firms for which data for consecutive periods are available is very small. Panel AR1 estimation, which considers the potential bias, therefore can only be applied to a small number of firms. Moreover, this estimation has too few degrees of freedom to consider firm-specific fixed
} 
effects, which the F-test and Hausman test reveal to be significant. The results of panel AR1 estimation, which are not reported but available upon request, do not appear to be very reliable.

${ }^{v}$ A specification with the control variables in levels (measured at the beginning of the period) provides similar results as a specification with the control variables in first differences and does not change the conclusions with respect to the outsourcing variables. The level of average employment has a statistically significant negative sign and the ratio of external to total $R \& D$ has a statistically significant positive sign. Including a quadratic term of the latter variable supports the view of Lokshin et al. (2007) that there is an optimal level of the ratio of external versus internal R\&D. However, Ramsey's RESET test for the specification with the control variables in levels is highly significant which calls for caution in interpreting these results. 